\title{
Surgical Technique
}

Chirurgia (2016) 111: 445-449

No. 5, September - October

Copyright@ Celsius

http://dx.doi.org/10.21614/chirurgia.111.5.445

\section{Supradentate Transmucosal Hemorrhoidopexy (Original Technical Variant)}

\author{
Ștefan Voiculescu' ${ }^{1}$, Elena Gabriela Voiculescu'², Răzvan Scăunașu' ${ }^{1}$ Cristian Bălălău \\ ${ }^{1}$ Colțea Surgical Clinic, Carol Davila University of Medicine and Pharmacy, Bucharest; Clinica Elite, Bucharest, Romania \\ ${ }^{2}$ Department of Gynaecology, R.A.T.B. Health Center, Bucharest; Clinica Elite, Bucharest, Romania \\ ${ }^{3}$ St. Pantelimon Hospital, Surgical Clinic, Carol Davila University of Medicine and Pharmacy, Bucharest, Romania
}

\section{Rezumat \\ Hemoroidopexia transmucoasă suprapectinată (variantă tehnică originală)}

Boala hemoroidală simptomatică reprezintă o problemă serioasă pentru calitatea vieții. Numeroasele tehnici intervenționale în uz reflectă eșecul în acoperirea tuturor aspectelor nosologice, fapt ce justifică căutarea de noi soluții operatorii. Cerințele unei noi tehnici operatorii sunt aplicabilitatea la categorii cât mai largi de pacienți, invazivitatea redusă, în contextul menținerii unor costuri rezonabile, unei eficacități corecte, unei morbidități și rate de recurență reduse, cu o tehnică suficient de simplă, reproductibilă și ușor de învățat. Țintind aceste obiective am conceput o variantă tehnică de hemoroidopexie aplicabilă în condițiile chirurgiei de zi, care nu necesită aparatură sau dispozitive medicale sofisticate/costisitoare și are un grad redus de invazivitate. Indicația operatorie a fost reprezentată de hemoroizii de grad II, III și IV. Anestezia necesară este cea regională (rahianestezia caudală), ceea ce o face aplicabilă practicii private. Reducerea prolapsului este urmată de pexia transmucoasă în 2 rânduri de suturi în X lent resorbabile decalate unul față de celălalt și plasate deasupra liniei pectinate. Rezultatele preliminarii sunt încurajatoare, atât ca rată de succes terapeutic, cât și ca lejeritate a urmărilor postoperatorii. Această hemoroidopexie este o tehnică simplă, ieftină, larg aplicabilă,

Corresponding author: $\quad$ Assist. Prof. Ștefan Voiculescu, PhD Colțea Surgical Clinic

blvd. I.C. Brătianu no.1, s3, Bucharest, RO Clinica Elite, Tudor Ștefan street, no.42-44 E-mail: s_voiculescu@yahoo.com generând dureri moderate, morbiditate scăzută și eficacitate bună, preferabilă altor tehnici pentru hemoroizii de grad III și cazuri selecționate de hemoroizi de grad IV.

Cuvinte cheie: hemoroizi, chirurgie de zi, hemoroidopexie

\section{Abstract}

Symptomatic hemorhoidal disease is a serious issue affecting the quality of life. The multiplicity of current interventional procedures reflects the failure of covering all pathological aspects, thus justifying the quest for other operative solutions. Any new operative procedure is challenged by the need for broad applicability and less invasive attributes and should fit inside the frame of reasonable costs, fair efficacy, low morbidity and recurrence rate based on a procedural technique that is simple enough, reproducible and easy-tolearn. Aiming to achieve these goals we conceived a procedural variant of hemohrhoidopexy fit for outpatient surgery, a technique that does not require sophisticated/costly medical equipment or disposables and is less invasive. The operative indication concerned $2^{\text {nd }}, 3^{\text {rd }}$ and $4^{\text {th }}$ grade hemorrhoids. The surgical indication was represented by $2^{\text {nd }}, 3^{\text {rd }}$ and $4^{\text {th }}$ grade hemorrhoids. The needed anesthesia is regional (caudal spinal anesthesia), which qualifies this procedure for private medical services. Prolapse reduction is followed by transmucosal suturing using two rows of slowly absorbable half-step staggered en-X stitches placed just above the dentate line. Preliminary results are encouraging both as therapeutic success rate and legerity of postoperative consequences. This hemorrhoidopexy is a simple 
and broadly applicable technique, causing mild pain, low morbidity and good efficacy, preferable to other techniques used to treat $3^{\text {rd }}$ grade and selected $4^{\text {th }}$ grade hemorrhoids.

Key words: hemorrhoids, one day surgery, hemorrhoidopexy

\section{Background}

Symptomatic hemorrhoidal disease has a significant impact on patients' social and professional life, thus inducing a serious preoccupation in curing it for them as well as for their doctors $(1,2)$.

The interventional attitude $(3,4)$ may involve physical and chemical procedures (Mitchell's sclerotherapy, atomization, cryosurgery, infrared, laser or radiofrequency coagulation), supradentate devascularisation [Baron's rubber banding, Pakravan's en Z-hemorrhoidopexy, Morinaga's hemorrhoid arterial ligation, De Longo's stapling hemorrhoidopexy (5)] or hemorrhoidectomies [segmental hemorrhoidectomy of Parks, Milligan-Morgan, Fergusson or their variants using the harmonic scalpel (6) or LigaSure (7) or the radical WhiteheadVercescu's procedure (1)].

Within this framework, the hemorrhoidopexies are defined as moderate operative techniques, conceived to achieve the persistent decrease of venous outflow while correctly repositioning the hemorrhoidal plexuses and their overlaying mucosa. The sophistication of the imagined procedures and of the equipment and disposables required for them happens to be proportional to the resources offered by the healthcare system of the countries of origin of these procedures' creators and promoters. This is outstanding for Morinaga's procedure (transanal ultrasound identification of the hemorrhoidal arterial branches by single use endorectal ultrasound probes and their transmucosal ligation using an on-purpose designed speculum and dedicated suturing consumables) and for De Longo's operation (automated suture using a special endorectal circular stapler) and quite modest for Pakravan's hemorrhoidopexy (transmucoasal en- $Z$ suture with limited excision (8), using trivial materials). Our constraining resources and the observation of some onerous principial sophistications in Morinaga's procedure case (9), completely unjustified by any supplemental efficacy, lead us to the dramatic technical abbreviation represented by the procedure described in the following section.

\section{Operative technique}

\section{Preparations}

Bowel preparation is not required, but rectal voidance would be desirable. The use of a frontally closed lateral window rectal speculum renders it optional. Preoperative bladder voidance is to be considered and so is perineal hair removal.

\section{Operation scenery}

The conditions offered by a room for small operations are more than sufficient, thus qualifying the procedure for office practice. The operating table may be a gynecological table ore one adaptable to this purpose. Obviously the respect of asepsy and antisepsy is mandatory, but the instruments and materials used are trivial. The presence of an assistant is not mandatory, but whenever the conditions are allowing, he is welcome. Even if the surgeon may perform the anesthesia by himself, the actual guidelines are claiming the involvement of an anesthesiologist for this task. One nurse is enough for this procedure.

\section{Instrumentarium and materials}

The instrumentarium has to include a rectal speculum (one with a lateral window will be appreciated), a needle-holder (a Hagedorn one is to be preferred to a Mathieu needle-holder!), scissors for stitches (curve or straight), a pair of $3 / 4$ surgical tweezers and a Kelly/Pean forceps (a curve one would be more helpful). A dozen of gauze pads and 3 or 4 threads of $2 / 0$ or $3 / 0$ slowly absorbable sutures attached to a $1 / 2$ circle round needle (polydioxanone, for example) are enough.

\section{Technique's description}

The patient lays in lithotomy position, with one peripheral venous catheter and a conventional saline infusion. After regional disinfection and operative field preparation the hemorrhoidal prolapse is evaluated and the external piles distribution is registered (Fig. 1). The hemorrhoidal prolapse is reduced (usually the simple passage of the rectal speculum is enough, as seen in Fig. 2). The dentate line and internal hemorrhoids are emphasized. The onset of en-X stitches (Fig. 3) starts in the five-o'clock position (for right-handed surgeons) at $0.5-1 \mathrm{~cm}$ cephalad from the dentate line. The suture advances clockwise on two half-step staggered rows (zigzag-like), anchoring with the cranial bite the rectal mucosa to the underneath

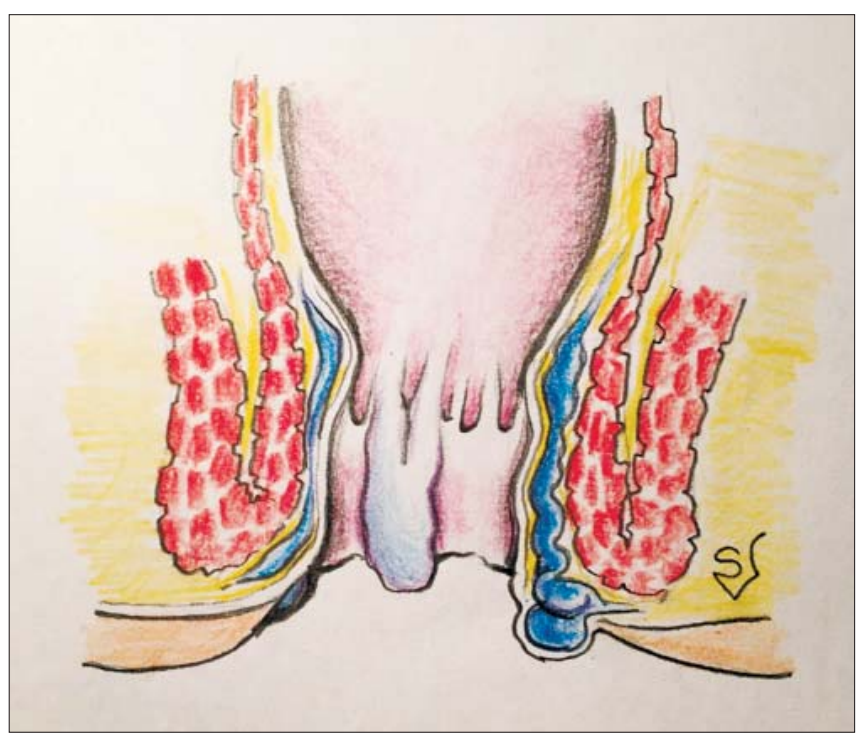

Figure 1. The initial image of internal and external hemorrhoids (grade III) 


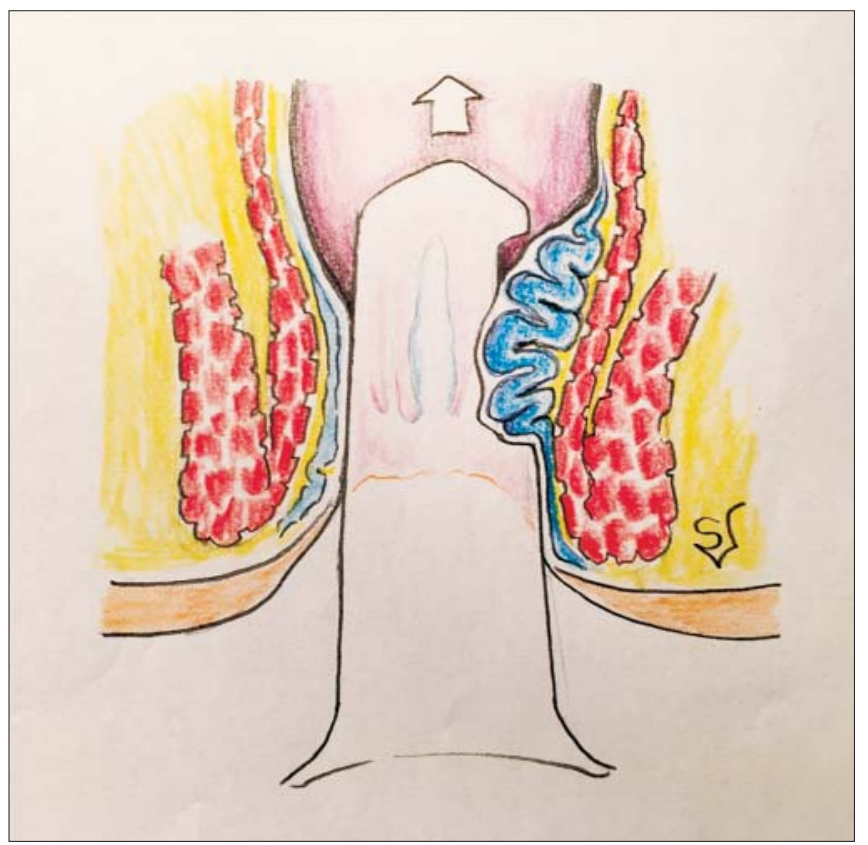

Figure 2. Introducing the side window rectal speculum accomplishes hemorrhoidal prolapse reduction

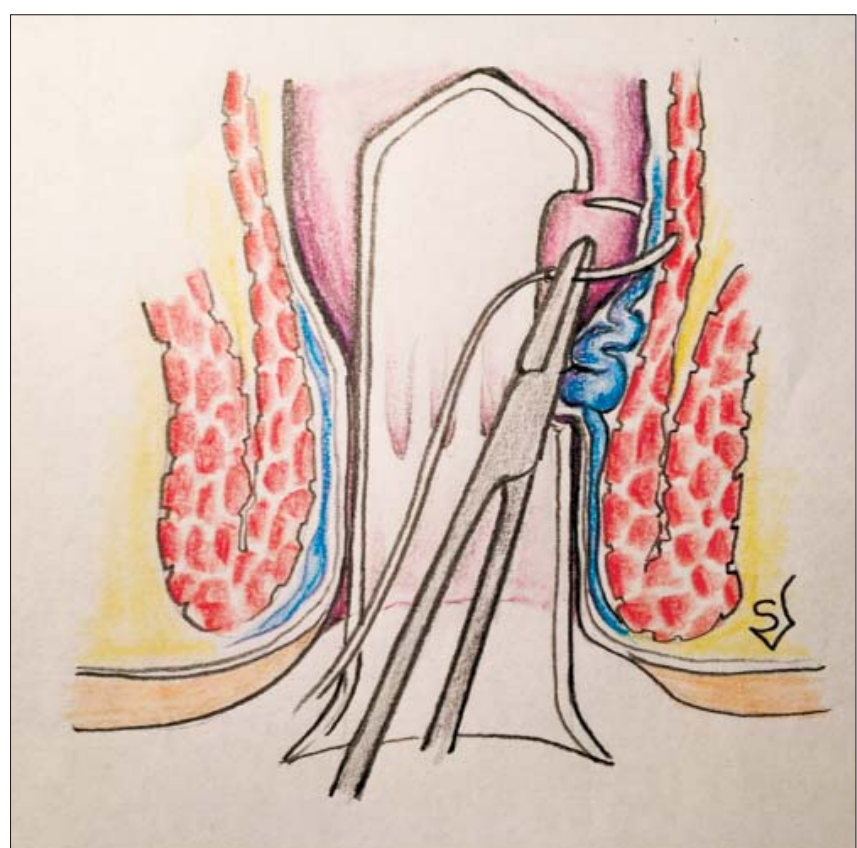

Figure 3. Starting the first row of transmucosal suprapectineal stitches

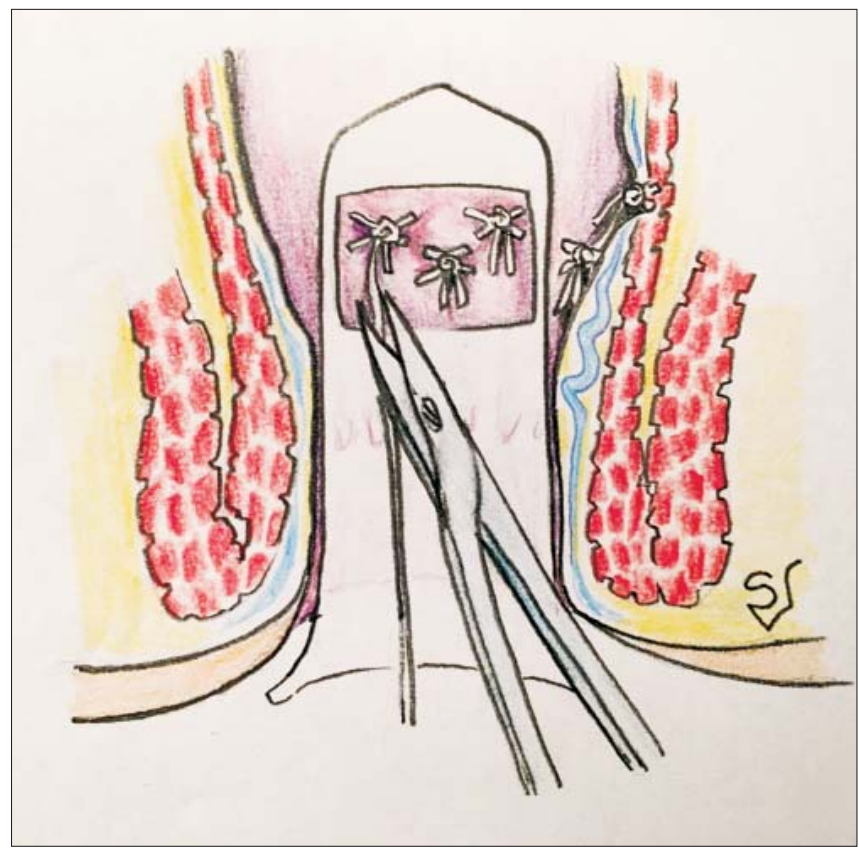

Figure 4. Complete two rows of staggered radial circumferential sutures

The patient may be submitted to this procedure in day surgery or hospitalized for one to maximum 2 days (thus some complications may occur after discharging the patient, so it is wise to schedule his medical follow up). Post procedural pain is usually mild and tend to be limited to the first postoperative week, and to be strained by pelvic diaphragm's contraction and rectal voiding.

Occasionally pain may be intense and/or persistent. We rarely noticed complications, such as:

- acute urinary retention (needing a bladder catheter);

muscular layer, eventually covering the cross-passed hemorpore vertical and encompassing more mucos of the rectal circumference avoids the risk of flooding by any unexpected (exceptional!) bleeding caused by vascular disruption. The suture threads are cut short (a few millimeters long, 4), lacking the elasticity change issue as catgut thread to cover the entire circumference (thus four $75 \mathrm{~cm}$ long threads correction of prolapse and deflation of piles compared to the operation's start (Fig. 6). Bleeding control may be achieved by supplemental en-X sutures. In fact, the total blood loss in this operative time is between 20 and 50 minutes depending on surgeon's ability and cases peculiarities, usually being of about 30 minutes. It proved to be very helpful to use in the postoperative period for 3 weeks 3 tablets per day of hesperidin-

\section{Morbidity}




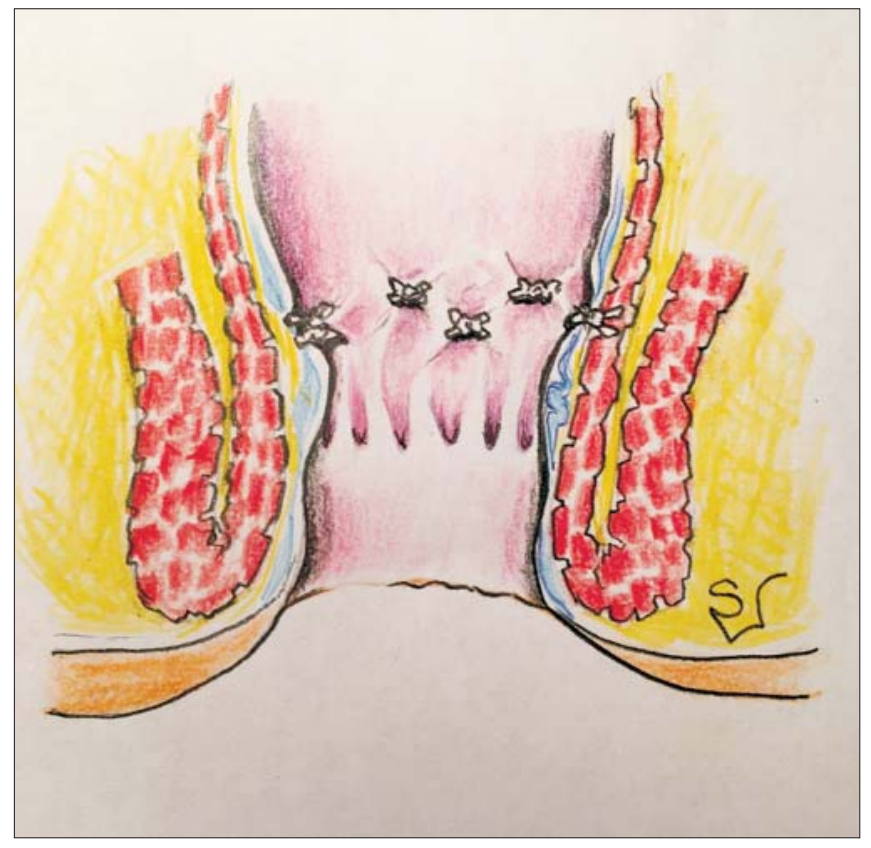

Figure 5. Final aspect

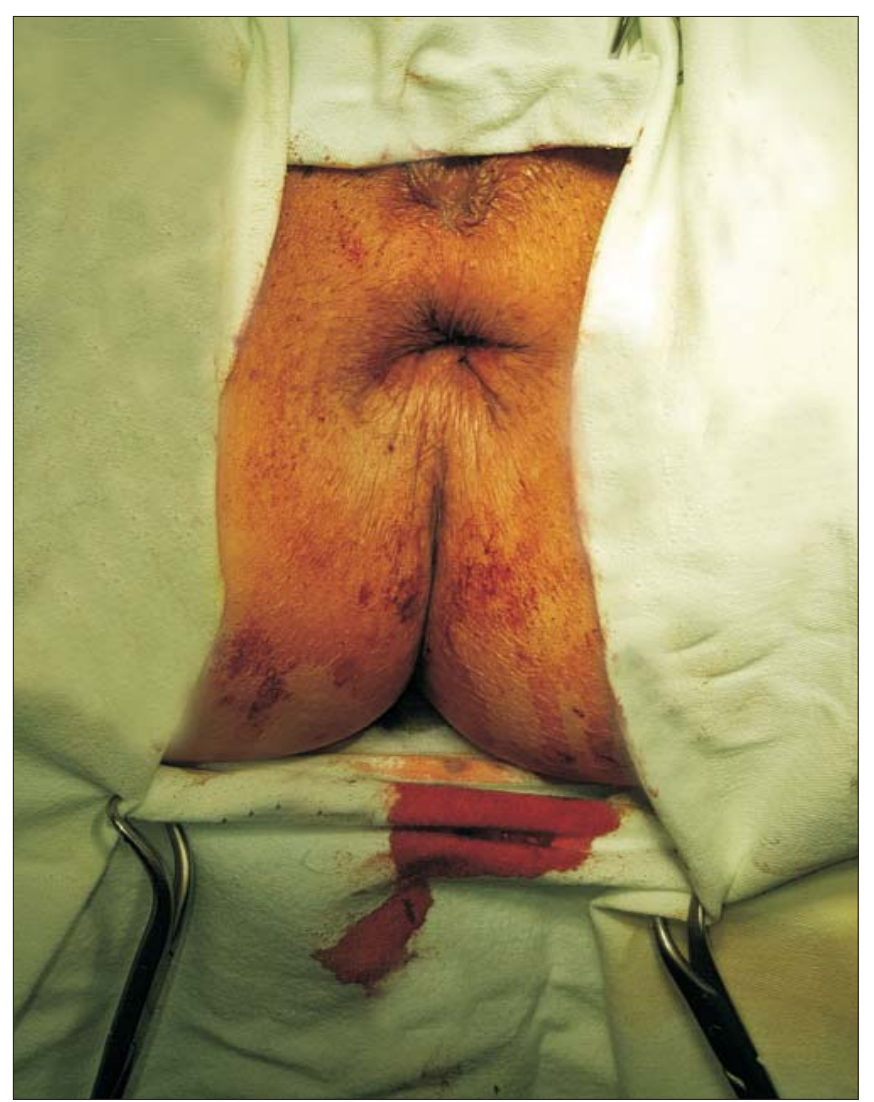

Figure 7. Postoperative image (prolapse reduction, minimal blood loss)

knowledge. Like the rubber banding, this procedure allows iterations.

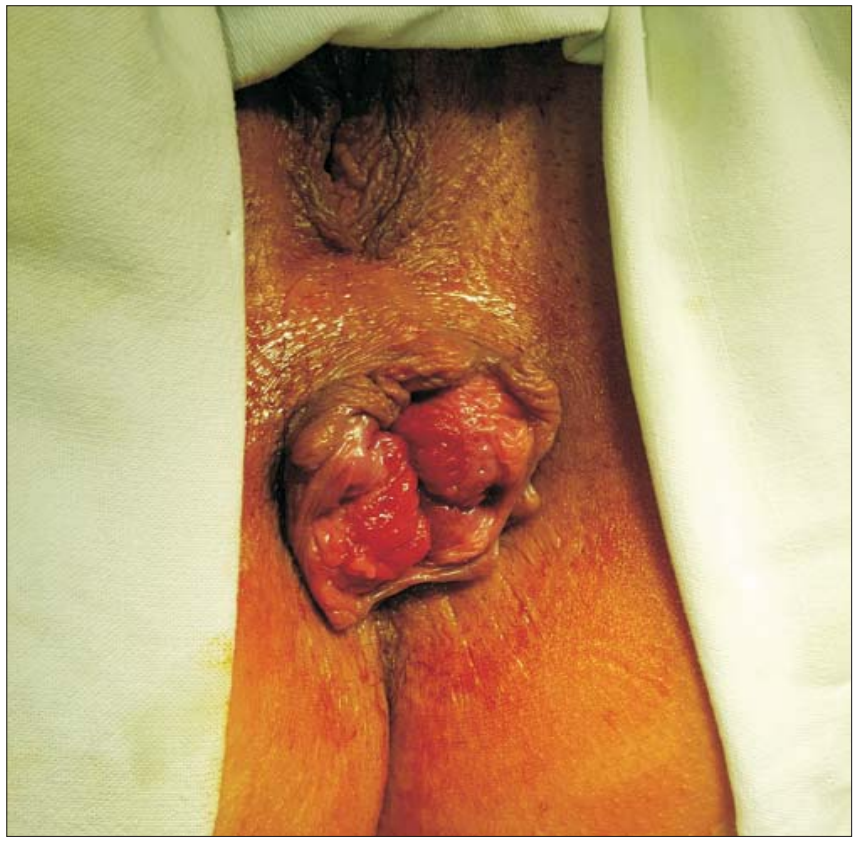

Figure 6. Preoperative image

\section{Procedure's assessment}

This supradentate hemorrhoidopexy proves itself to be a simple, inexpensive, largely applicable and less invasive procedure, carrying a low morbidity and fair efficacy as compared with alternative methods.

Retrospectively, we may consider that supradentate transmucosal hemorrhoidopexy is a good choice for patients with $3^{\text {rd }}$ degree and selected cases of $4^{\text {th }}$ degree hemorrhoid, but for $2^{\text {nd }}$ degree hemorrhoids the similar efficacy of Baron's rubber banding seems to be more beneficial.

\section{Selective references}

1. Mandache F. Chirurgia rectului. București: Ed. Med.; 1971. p. 451-72.

2. Rădulescu D, Belușică L. Caiete de chirurgie practică, vol. 2, ediția a 2-a. București: Ed. Med.; 1999. p. 199-234.

3. Chaudhry V, Abcarian H. Hemorrhoids. In: Cameron J, Cameron AM, editors. Current Surgical Therapy, 11th edition. Elsevier-Saunders; 2014:255-262.

4. Rivadeneira DE, Steele SR, Ternent C, Chalasani S, Buie WD, Rafferty JL, et al. Practice parameters for the management of hemorrhoids (revised 2010). Dis Colon Rectum. 2011;54(9):1059-64. doi: 10.1097/DCR.0b013e318225513d.

5. Rahman ASMT, Rahman ASMZ, Biswas SK, Majumder KR, Biswas G. Stapled Haemorrhoidopexy Compared with Conventional Haemorrhoidectomy-A Systematic Review, Faridpur Med. Coll. J., 2012,7(1): 37-41.

6. Bilgin Y, Hot S, Barlas İS, Akan A, Eryavuz Y. Short - and long-term results of harmonic scalpel hemorrhoidectomy versus stapler hemorrhoidopexy in treatment of hemorrhoidal disease. Asian J Surg. 2015;38(4):214-9. doi: 10.1016/j. asjsur.2014.09.004. Epub 2014 Nov 4. 
7. Madoff RD. LigaSure hemorrhoidectomy versus stapled hemorrhoidopexy: a prospective, randomized clinical trial: retraction. Dis Colon Rectum. 2014;57(9):1151. doi: 10.1097/ 01.dcr.0000453521.88176.59.

8. Pakravan F1, Helmes C, Baeten C. Transanal open hemorrhoidopexy. Dis Colon Rectum. 2009;52(3):503-6. doi: 10.1007/ DCR.0b013e318197d703.
9. Walega P, Romaniszyn M, Kenig J, Herman R, Nowak W. Doppler-guided hemorrhoid artery ligation with RectoAnal-Repair modification: functional evaluation and safety assessment of a new minimally invasive method of treatment of advanced hemorrhoidal disease. Scientific World Journal. 2012;2012:324040. doi: 10.1100/ 2012/324040. Epub 2012 Apr 1. 